\title{
STRATEGI MENGEMBANGKAN KREATIVITAS MAHASISWA DALAM PEMBELAJARAN TATA BUSANA
}

\author{
Weni Nelmira \\ Universitas Negeri Padang \\ E-mail : weninelmira@yahoo.com
}

\begin{abstract}
Creativity is an important role in the education of Fashion Education because only creative individuals can produce creative ideas and products. The Fashion Education has to perform its function for the formation of character, work culture, personality, skill, knowledge, behavior and various life skill according to the demands of work world. Fashion Education is still not maximized in developing the creativity of students, especially the ability to think creatively in solving the problems of daily life that it faces. For that required the creativity of educators to foster student creativity. Student creativity will emerge, if the teacher as a pilot in the classroom also has adequate creativity. The subject matter that has been prepared in the syllabus, should be well developed to achieve the predetermined educational objectives. The development of creativity can be done with brainstorming learning, giving motivation, bringing creative people to school and not limit the student excessively by directing students to express and actualize themselves in relation to oneself, to nature, and to others.
\end{abstract}

Keywords : Strategy, creativity, Fashion Education

\section{PENDAHULUAN}

Kreatifitas mahasiswa pada pendidikan Tata Busana perlu dipupuk dan dikembangkan karena pribadi yang kreatif akan mampu melahirkan gagasan dan karya-karya yang inovatif. Pada pendidikan Tata Busana kreatifitas memegang peranan penting. Tingkat kreatifitas mahasiswa dapat dilihat dari gagasan-gagasan yang dilahirkan dan dituangkan dalam karya yang dihasilkannya. Tanpa kreatifitas yang tinggi tentunya karya yang dihasilkan kurang diminati oleh konsumen sehingga pembinaan kretifitas pada pendidikan tata busana menjadi pembinaan yang bersifat urgen dan perlu ditumbuhkembangkan melalui pembelajaran di kelas.

Pendidikan Tata Busana pada dasarnya adalah salah satu pendidikan vokasi. Menurut Sangari (2013) pendidikan vokasi yaitu pendidikan yang diarahkan pada penguasaan dan pengembangan keahlian terapan, beradapatasi pada bidang pekerjaan tertentu dan dapat menciptakan peluang kerja. Kompetensi mahasiswa tidak hanya mempelajari aspek kognitif dan afektif saja, tetapi mengedepankan aspek psikomotorik yang memiliki skill, attitude dan knowledge, berkarakter, beretos kerja tinggi, sehingga lulusannya siap pakai dipasar kerja atau siap mandiri dengan skill yang 
dimilikinya. Untuk mencapai tujuan tersebut perlu dilakukan pembinaan terhadap mahasiswa, salah satunya yaitu pembinaan kreatifitas mahasiswa sehingga tercipta lulusan yang handal, memiliki kreatifitas dan inovatif yang siap pakai dan kompeten dibidangnya sesuai kebutuhan dunia kerja.

Kreatif atau tidaknya seseorang menurut Rahayu (2012) adalah sebuah pilihan sebagaimana juga pilihan seseorang terhadap kehidupan yang ia jalani. Sebab, pada dasarnya semua orang dapat menjadi orang yang kreatif dan penuh imajinatif. Carol K. Bowman dalam Rahayu (2012) menyatakan bahwa setiap orang memiliki kreativitas. Artinya, siapapun dia, dari suku manapun, dari keluarga apapun, dari wilayah manapun, bahkan berapapun usianya, semua memiliki anugerah berupa kemampuan menjadi kreatif dan inovatif. Intinya, setiap orang yang memiliki otak yang masih berfungsi dengan baik, mampu berpikir kreatif atau memiliki energi kreativitas dalam dirinya. Namun tanpa adanya usaha untuk mengembangkan kreativitas ini tentunya potensi kreativitas yang sudah dimiliki tidak akan berkembang. Oleh sebab itu usaha pembinaan dan pengembangan kreativitas siswa dikelas perlu dilakukan dalam mengoptimalkan pengembangan kreativitas yang sudah dimiliki siswa.

Proses pembelajaran yang dilakukan dewasa ini di dalam kelas, menunjukkan bahwa betapa pembelajaran di sekolah masih belum dapat meningkatkan kreativitas siswa secara maksimal, khususnya kemampuan berpikir kreatif dalam memecahkan masalah kehidupan seharihari yang dihadapinya. Konsekuensi dari cara mengajar guru yang cenderung tidak melibatkan siswa secara aktif dalam pembelajaran tidak dapat membentuk siswa menjadi pribadi yang kreatif dan mandiri. Padahal siswa yang kreatif, akan mampu mencari jalan keluar bagaimana dia dapat membantu dirinya dan orang lain, dan mampu memecahkan masalah yang dihadapinya dengan baik. Hal tersebut sejalan dengan apa yang dikatakan oleh Treffinger dalam Munandar (1999) bahwa dengan belajar secara kreatif siswa dapat menciptakan kemungkinankemungkinan untuk memecahkan masalah-masalah yang tidak diramalkan sebelumnya.

Melalui tulisan ini akan dibahas hal-hal yang berkaitan dengan kreativitas dan strategi pengembangan kreativitas siswa/mahasiswa pada pembelajaran Tata Busana yang diharapkan dapat bermanfaat bagi pembaca semua.

\section{PEMBAHASAN}

\section{Pembelajaran Tata Busana}

Belajar dan pembelajaran merupakan dua hal yang tidak terpisahkan. Belajar dapat dilaksanakan dimana saja dan kapan saja asalkan tersedia sumber belajar dan objek yang akan di pelajari pada suatu lingkungan belajar. Begitu juga dalam pembelajaran bidang keahlian Tata Busana. Proses pembelajaran secara formal bertujuan untuk mengarahkan perubahan pada diri peserta didik 
secara terencana baik aspek kognitif, afektif maupun psikomotornya.

Trianto

mengemukakan masalah utama dalam pembelajaran pada pendidikan formal dewasa ini adalah masih rendahnya daya serap peserta didik. Hal ini terlihat dari rerata hasil belajar peserta didik yang senantiasa masih sangat memprihatinkan. Prestasi ini merupakan hasil kondisi pembelajaran yang masih bersifat konvensional dan tidak menyentuh ranah dimensi peserta didik itu sendiri yaitu bagaimana sebenarnya belajar itu (belajar untuk belajar). Dalam arti yang lebih substansial proses pembelajaran dewasa ini masih memberikan dominasi guru dan tidak memberikan akses berkembang secara mandiri kepada siswa melalui penemuan dalam proses berfikirnya.

Pembelajaran Tata Busana mempunyai karakteristik tersendiri, yang sarat dengan pengaplikasian strategi pembelajaran keterampilan secara bervariasi. Pada pembelajaran Tata Busana penting untuk dicarikan pendekatan yang tepat dengan menerapkan berbagai strategi pembelajaran. Sebagai salah satu pendidikan vokasi, maka proporsi mata kuliah praktek lebih banyak dibandingkan teori yaitu $60 \%$ praktek dan $40 \%$ teori. Sebagaimana pada pembelajaran pada umumnya, maka pada pencapaian tujuan pembelajaran bidang Tata Busana, melibatkan tiga aspek yaitu aspek kognitif, afektif dan psikomotor. Bloom, dkk (2001:62) mengemukakan domain kognitif mencakup beberapa tingkat penguasaan yaitu pengetahuan, pemahaman, penerapan, analisis, sintesis, dan evaluasi. Domain afektif meliputi; menerima, menanggapi, menghargai, dan mengkarakterisasi. Domain psikomotor adalah ; hasil usaha yang diperoleh seseorang akibat aktifitas personal yang menimbulkan perubahan kemampuan dan penampilan dalam meniru, memanipulasi, melakukan dan gerakan tepat, artikulasi dan naturalisasi.

Karena pendidikan Tata Busana merupakan pendidikan vokasional maka tujuan pendidikannya adalah untuk mempersiapkan tenaga kerja, maka orientasi kurikulumnya tertuju kepada output atau lulusannya yang kompeten. Di sini dapat dijelaskan bahwa keberhasilan pendidikan vokasional berupa lulusan dari lembaga pendidikan berorientasi kepada penampilan (performance, unjuk kerja) lulusan itu di lapangan kerjanya.

Kriteria keberhasilan pendidikan Tata Busana harus dilihat dari keberhasilan di sekolah (in-school success) dan keberhasilan di luar sekolah (out-of-school success). Agar keberhasilan kedua aspek ini tercapai maka pembinaan dalam pembelajaran sangat penting untuk memperhatikan berbagai aspek yang terlibat, baik guru, siswa, sarana prasarana, dan aspek lain yang mendukung. Sinergi antara semua komponen di atas akan dapat menghasilkan output berupa siswa yang kompeten yang sesuai dengan kebutuhan dunia kerja baik 
dari segi soft skill yang dimiliki maupun hard skillnya.

\section{Kreatifitas}

Kreativitas menurut Samosir (1992:11) adalah kemampuan untuk mencipta/berkreasi. Supriadi (2001) mendefinisikan kreativitas sebagai kemampuan untuk melahirkan sesuatu yang baru baik berupa gagasan maupun karya nyata yang relatif berbeda dengan apa yang telah ada sebelumnya. Di lain pihak Munandar (1999) mengartikan kreativitas sebagai kemampuan untuk membuat kombinasi baru berdasarkan data, informasi, atau unsur-unsur yang telah ada atau telah dikenal sebelumnya, yaitu semua pengalaman dan pengetahuan yang telah diperoleh seseorang selama hidupnya, baik itu di lingkungan sekolah, keluarga, maupun dari lingkungan masyarakat. Sementara itu, Amin (1980:20) menyatakan kreativitas sebagai suatu pola berpikir atau ide yang timbul secara spontan dan imajinatif, yang mencirikan hasil artistik, penemuan ilmiah, dan penciptaan baru, baik sama sekali baru dalam dunia ilmiah maupun relatif baru bagi individu itu sendiri, walaupun mungkin orang lain telah menemukan atau memproduksi sebelumnya.

Jadi dapat disimpulkan bahwa kreativitas adalah kemampuan seseorang untuk berkreasi guna melahirkan suatu gagasan maupun karya nyata yang baru, kombinasi baru, atau sesuatu yang relatif berbeda dengan apa yang telah dia ketahui sebelumnya, baik sama sekali berupa produk baru yang belum pernah diproduksi di dunia ini maupun produk yang telah diproduksi orang lain tetapi relatif baru bagi individu itu sendiri.

\section{Ciri-ciri Kreativitas}

Munandar (1999) membedakan ciri-ciri orang kreatif dalam dua kelompok, yaitu ciri-ciri kognitif (kemampuan berpikir) dan ciri-ciri afektif. Ciri-ciri kognitif meliputi kelancaran, fleksibilitas, dan orisinalitas. Secara rinci dapat dijelaskan sebagai berikut :

a. Kelancaran ini menunjukkan pada kemampuan untuk menciptakan ide-ide sebagai alternatif pemecahan masalah. Orang yang kreatif memiliki kemampuan untuk mengajukan ide-ide atau alternatif pemecahan masalah. Untuk dapat menghasilkan ide-ide diperlukan adanya pengetahuan yang luas tetapi juga dalam. Orang yang kreatif memiliki kemampuan melihat masalah dari bermacammacam sudut pandang sehingga lebih mampu menciptakan ide-ide atau alternatif pemecahan masalah dari bermacam-macam sudut pandang.

b. Fleksibilitas (kelenturan), hal ini menunjuk pada kemampuan memindahkan ide, meninggalkan satu kerangka pikir untuk kerangka pikir lain, untuk mengganti pendekatan satu dengan pendekatan lain. Orang kreatif tidak terlalu terikat pada cara-cara pemecahan masalah yang biasa digunakan, sebaliknya dia selalu berupaya menemukan alternatif baru untuk 
memecahkan masalah lebih efektif lagi. Orang kreatif selalu bertanya dalam dirinya, apa yang lain?

c. Orisinalitas (keaslian pemikiran), menunjuk pada kemampuan menciptakan pemikiran atau ide-ide yang asli dari dirinya. Orang yang kreatif memiliki kemampuan menciptakan ide atau pemikiran dalam bentuk baru, imajinatif, orisinal dan berbeda dengan ide-ide pemecahan masalah yang lama. Orang kreatif dapat menjangkau di luar pemikiran orang biasa, dia berpikir dengan cara yang unik melampaui cara-cara yang biasa digunakan, orang kreatif lebih terbuka terhadap ide-ide baru, dia mudah menerima ide-ide baru, baik itu idenya sendiri maupun orang lain.

Selanjutnya ciri-ciri afektif dari kreatifitas meliputi : motivasi atau dorongan dari dalam untuk berbuat sesuatu, pengabdian atau pengikatan diri terhadap suatu tugas, rasa ingin tahu, tertarik terhadap tugas-tugas majemuk yang dirasakan sebagai tantangan, berani mengambil resiko untuk membuat kesalahan atau untuk dikritik oleh orang lain, tidak mudah putus asa, menghargai keindahan, mempunyai rasa humor, ingin mencari pengalaman-pengalaman baru dan dapat menghargai baik diri sendiri maupun orang lain. Jika ciri-ciri kreativitas dikaitkan dengan kepribadian seseorang, maka akan tampak karakteristik pribadi yang kreatif.
Beberapa

karakteristik

kepribadian orang kreatif menurut Munandar (1999) adalah : 1. Mandiri dalam sikap dan perilaku sosial. 2 . Keterbukaan terhadap rangsangan dari luar. 3. Memiliki minat yang luas dan rasa ingin tahu. 4. Kepercayaan terhadap diri sendiri. 5. Memperhatikan kekuatan firasat dan ketidaksadaran. 6 . Keteguhan dan ketabahan hati dalam menghadapi kesulitan. 7. Kemampuan menggunakan kekuatan imajinasi untuk menciptakan ide-ide baru. 8. Motivasi intrinsik dalam bekerja dan berkarya. 9 . Menggunakan kekuatan perasaan termasuk firasat dan ketidaksadaran dalam memecahkan masalah. 10. Kelancaran, kelenturan, dan keaslian dalam berpikir untuk menemukan alternatif dalam melihat masalah kehidupan. 11. Ketajaman dan kepekaan dalam melihat masalah kehidupan. 12. Kemampuan berpikir analisis dan sintetis dalam memecahkan masalah. 13. Memiliki pengamatan yang tajam terhadap fakta dan realita kehidupan. 14. Memiliki sensitivitas terhadap keindahan dan menggunakan sebagai kekuatan untuk berpikir baru dan memecahkan masalah. Karakteristik kepribadian kreatif semacam itu berlaku bagi semua orang, baik anak-anak, pemuda, dan orang dewasa. Namun tentu saja berbeda dalam taraf kematangannya sebab sebagaimana diketahui bahwa anak adalah dalam proses pembelajaran.

$$
\text { Selanjutnya Rahayu (2012) }
$$
mengemukakan gaya kreativitas dapat dikelompokan menjadi dua gaya yaitu : 
a. Adaptif problem solving, yaitu model kreativitas yang cenderung berpikir dan bekerja untuk menyempurnakan sistem yang sudah ada. Orang-orang yang berada dalam kelompok ini sangat kreatif melakukan perbaikan terhadap sesuatu yang telah ada sehingga menjadi lebih baik, lebih cepat, lebih efektif, lebih efisien, lebih murah, lebih indah, dan sebagainya.

b. Innovatif problem solving, yaitu cara berpikir atau bekerja yang cenderung menantang atau mengubah sistem yang sudah ada. Orang-orang yang berada dalam kelompok ini lebih berorientasi dan sangat kreatif menemukan hal-hal yang berbeda dari kebiasaan sehingga sering menjadi agent of change, kontak atau orang-orang pembawa pembaharuan. Olek karena itu orang-orang yang ada dalam kelompok ini seperti melawan arus atau terlihat berani melakukan hal-hal yang tidak lazim.

\section{c. Strategi kreatifitas}

mengembangkan

Torrance dalam Ali (2011:43), kreativitas itu bukan semata-mata bakat kreatif atau kemampuan kreatif yang dibawa sejak lahir, melainkan hasil dari hubungan interaktif dan dialektis antara potensi kreatif individu dengan proses belajar dan pengalaman dari lingkungan. Secara tegas, ia mengatakan setiap individu memiliki potensi kreatif, tetapi kenyataannya tidak semua berwujud menjadi kemampuan dan kemampuan kreatif.

Kreativitas seseorang dapat dirangsang, diasah, dan dilatih terusmenerus supaya meningkat. Caracara merangsang, mengasah, dan melatih kreatifitas menurut Rahayu (2012) diantaranya adalah:

1. Bersikap proaktif, dalam arti membebaskan pikiran memilih apapun ide dan tindakan kreatif yang terlintas dalam alam pikiran kita. Mungkin terkadang muncul rasa khawatir, ragu-ragu, atau malu dengan ide yang terlintas dalam pikiran kita. Tapi, apapun bentuk ide itu lahirkan saja, kalau perlu tuliskan dengan lengkap dan jelas.

2. Terbuka terhadap masukan, artinya mau mendengarkan berbagai ide, masukan, pendapat, usaha, atau bahkan kritikan orang lain.

3. Melakukan eksperimen baru tanpa takut melakukan kesalahan atau takut menerima kegagalan.

4. Mempertajam keterampilan dalam hobi karena dapat meningkatkan kreativitas otak sehingga mampu melahirkan ideide segar.

5. Membina hubungan yang luas dengan beragam lingkungan, karakter, dan komunitas berbeda guna memberi kesempatan tumbuhnya kreativitas baru yang mungkin tidak diketahui sebelumnya.

Alat pengukur yang sering digunakan untuk menentukan tingkat 
kreativitas seseorang menurut Samosir (1992) adalah "nilai gagasan kreatif tersebut". Orang-orang ahli menyatakan bahwa "tidak ada yang lebih menakutkan dari pada kreativitas tanpa cita rasa". Banyak definisi kreativitas yang menuntut bahwa hasil akhir suatu kreativitas harus memiliki cita rasa atau bernilai. Namun, tidak semua orang berhak menentukan bernilai atau tidak bernilainya suatu kreativitas. Sebab, boleh jadi hasil kreativitas seseorang sangat bernilai bagi dirinya sendiri sementara bagi orang lain tidak berarti apa-apa.

Kreativitas seseorang dapat meningkat atau menurun. Turun naiknya tingkat kreativitas dapat dirasakan sendiri oleh individu yang bersangkutan. Oleh sebab itu kreativitas seseorang tentu dapat diukur. Pengukuran kreativitas dapat dilakukan secara sederhana atau alami maupun dengan menggunakan metode ilmiah. Kreativitas dalam bidang tata busana dapat dilihat atau diukur dari tingkat produktivitas atau kuantitas produk yang dihasilkan. Semakin banyak karya yang dihasilkan seorang desainer berarti semakin tinggi tingkat kreativitasnya. Sebaliknya, semakin sedikit karya/gagasan yang dihasilkan berarti semakin rendah tingkat kreativitasnya.

$$
\text { Dalam mengembangkan }
$$

kreativitas ini guru sangat diharapkan berperan yang aktif untuk memberikan pemahaman pada siswa yang menjadi peserta didiknya. Strategi pengembangan kreativitas dalam pembelajaran Tata Busana dapat merujuk ke pendapat Ormrod (2011) $\begin{array}{lrrr}\text { menjelaskan } & \text { strategi } & \text { untuk } \\ \text { meningkatkan } & \text { kreativitas } & \text { di } & \text { kelas }\end{array}$ meningkatkan kreativitas di kelas adalah:

a. Tunjukan kepada siswa bahwa kreativitas itu dihargai.

b. Fokuskan perhatian siswa pada penghargaan internal dari pada penghargaan ekternal.

c. Dorong siswa menguasai suatu area mata pelajaran.

d. Berikan pertanyaan yang mengasah pikiran.

e. Berikan siswa kebebasan dan rasa aman yang dibutuhkan untuk mengambil resiko.

f. Sediakan waktu yang memadai untuk mendorong tumbuhkembangnya kreativitas.

Selanjutnya usaha-usaha yang dapat dilakukan orang tua dan guru dalam mengembangkan kreatifitas anak adalah:

a. Membantu anak/peserta didik untuk memahami latar belakang mereka, pengalaman mereka dan kebiasaan perilaku. Pada cara ini izinkan masing-masing pribadi untuk mengembangkan potensi dirinya.

b. Guru dan orang tua dapat menciptakan suasana untuk mendorong pemikiran kreatif dengan menghilangkan halangan luar dari kreativitas. Sensitifitas pada problem ditingkatkan, metode untuk membahas membebaskan imajinasi dapat dikembangkan dan sarana sistematis untuk mengevaluasi ide-ide dapat diajarkan pula.

c. Anak/peserta didik diberi kesempatan untuk mempraktekkan 
pemikiran kreatif dalam suasana yang terkendali dan terkontrol.

d. Cara-cara mengembangkan imajinasi anak/peserta didik dengan memberikan masalah-masalah yang dapat meningkatkan inteligensi remaja untuk membuahkan ide-ide yang baik, kriteria yang berbeda pada keunikan dan kegunaan.

e. Guru dan orang tua harus memberikan cara instruksi yang semantik didalam menerapkan imajinasi yang dapat menghasilkan pengembangan potensi yang ada pada diri remaja.

Dalam pembelajaran di kelas guru/dosen hendaklah melakukan kegiatan yang memupuk kreatifitas dalam proses belajar mengajar yaitu :

a. Libatkan anak dalam kegiatan Brainstorming, sehingga menghasilkan sebanyak mungkin ide. Brainstorming adalah sebuah kegiatan yang memberikan kebebasan anak untuk mengutarakan pikiran-pikirannya secara bebas mengenai sebuah ide tertentu. Brainstorming ini merupakan sebuah teknik dimana anak didorong untuk berani mengutarakan ide-ide (kreatif) nya dalam sebuah kelompok, menyajikannya bersama ide-ide orang lain, dan mengatakan apa yang ada dalam pikirannya. Temanteman yang mendengarkan disarankan untuk menahan diri untuk tidak menyampaikan kritik, paling tidak hingga akhir presentasi. Hal ini perlu dilakukan agar anak berani mengemukakan ide-idenya, apapun idenya. Waktu untuk menyampaikan ide-ide itu perlu dijadwalkan agar anak mau mengeluarkan sebanyak-banyak idenya walaupun ide tersebut tidak kreatif. Makin banyak ide yang dikeluarkan oleh anak, maka makin besar kemungkinan dia mengkreasikan sesuatu yang unik. Anak yang kreatif tidak takut untuk gagal dan tidak takut melakukan kesalahan. Mereka mungkin saja memasuki 20 kali jalan buntu sebelum dia bisa mengutarakan/ menemukan sebuah ide yang inovatif. Anak harus diarahkan berani menghadapi risiko tersebut.

b. Ciptakan lingkungan belajar sedemikian rupa, sehingga dapat menstimulasi (merangsang) kreativitas anak. Setiap anak memiliki rasa ingin tahu yang alami. Guru yang ingin mengembangkan kreatifitas anak bisa mengandalkan rasa ingin tahu pada anak tersebut sebagai sebuah sarana agar anak bisa bebas berpikir. Untuk itu sebaiknya guru melakukan kegiatan-kegiatan yang justru membuat anak mencari jawaban-jawaban yang muncul dari pikiran anak sendiri, tidak mengajukan pertanyaan-pertanyaan yang jawabannya harus dihafal, yang ada dalam benak guru atau dalam pikiran guru. Guru bisa juga merangsang kreatifitas dengan cara mengajak anak-anak ketempattempat dimana kreativitas ditampilkan, misalnya di berbagai galeri busana, studi banding ke 
tempat-tempat desainer busana, kunjungi sekolah-sekolah sejenis yang dapat melihatkan ke siswa karya-karya siswa lain yang kreatif, dan lain-lain.

c. Hindari mengendalikan anak secara berlebihan. Hasil penelitian mengungkapkan bahwa mengajarkan pada anak hal apa saja yang harus dilakukan, membuat mereka beranggapan bahwa hal yang original itu salah, buruk, dan bahwa kegiatan menjelajah (eksplorasi) itu adalah perbuatan yang sia-sia. Memberi kesempatan pada anak untuk memilih sesuatu hal sesuai minatnya dan mendukung minatnya tersebut yang mungkin berbeda dari anak lain, akan meningkatkan rasa ingin tahunya. Hal ini akan lebih baik, dari pada guru mendiktekan aktivitas-aktivitas mana yang harus mereka kerjakan. Bila orangtua atau guru terus menerus menunggui anak maka anak akan merasa bahwa dia (pekerjaannya) selalu diawasi. Bila anak merasa diawasi terus maka semangat untuk berpetualang, maupun keberanian untuk mengambil risiko melakukan kreatifitas bisa menjadi surut, dan mereda. Hal lain yang bisa merusak kreatifitas anak adalah harapan atau tuntutan yang terlalu tinggi agar anak menunjukkan prestasi kerja, dan agar dia melakukan segala sesuatu secara sempurna.

d. Kembangkan motivasi yang ada dalam diri anak. Kegiatan-kegiatan kreatif yang dilakukan anak secara bebas, menimbulkan sebuah kesenangan tersendiri bagi anak. Oleh karena itu, penggunaan hadiah yang terlalu eksesif (misalnya mainan, uang atau benda-benda lain) bisa menghambat kreatifitas. Karena kesenangan yang muncul sebagai akibat dari kegiatankegiatan kreatif itu sendiri menjadi pudar oleh hadirnya iming-iming hadiah. (Santrock. 2008).

e. Kembangkan cara berpikir fleksibel, dengan cara yang menyenangkan. Seorang pemikir yang kreatif pada saat menghadapi masalah, dia bersikap fleksibel dan cenderung mengolah masalah. Dalam proses ini akan sering muncul paradoks (hal-hal yang bertentangan). Usaha untuk berpikir kreatif akan berjalan lancar bila siswa menghadapinya dengan senang hati. Dalam bahasa sederhananya, humor bisa menjadi pelumas dari roda-roda kreatifitas. Pada saat anak "bercanda ria" mereka cenderung menampilkan pemecahan-pemecahan masalah yang tidak biasa, yang unik. Bersenang-senang dan bergurau, akan membantu melepaskan sensor dalam diri yang biasanya memarahi, mengutuk, melarang, ide-ide bebas anak sebagai sebuah hal yang kurang baik.

f. Hadirkan orang-orang yang kreatif ke lingkungan sekolah dan produkproduk kreatif yang dihasilkannya sehingga anak bisa mendapat pengalaman kreatif. Minta mereka menerangkan pada anak-anak hal 
apa atau pengalaman apa yang membuat mereka menjadi orang yang kreatif. Bisa juga tokoh yang kreatif itu diminta menampilkan kemampuan kreatifnya. Guru bisa mengundang desainer, pengrajin, pengusaha sulaman atau siapa saja, bisa membawa barang-barang yang dia miliki atau hasil-hasil karyanya ke dalam kelas, sehingga kelas menjadi semacam podium/teater yang menyajikan kreatifitasnya pada anak-anak. Hal ini membuat anak berfikir kreatif.

Berdasarkan uraian di atas penting untuk semua dosen/guru mendorong anak untuk kreatif dengan cara melibatkan melibatkan anak dalam kegiatan brainstorming sehingga menghasilkan sebanyak mungkin ide kreatif pada anak, menciptakan lingkungan yang dapat menstimulasi (merangsang) kreativitas anak, menghindari mengendalikan anak secara berlebihan agar anak dapat memilih sesuatu hal sesuai minatnya dan mengembangkan imajinasinya dan hadirkan orang-orang kreatif yang membuat anak memeperoleh share ilmu pengetahuan dari orang-orang yang kreatif serta perlihatkan berbagai produk kreatif yang ada sehingga anak terstimuli untuk menjadi pribadi yang kreatif juga.

\section{PENUTUP}

\section{Kesimpulan}

Berdasarkan uraian di atas dapat disimpulkan bahwa strategi pengembangan kreatifitas siswa/mahasiswa sangat penting dilakukan. Kreativitas siswa mencakup aspek kognitif, afektif dan psikomotor. Untuk mengembangkan kreativitas siswa/mahasiswa dapat dilakukan dengan cara bersikap proaktif, terbuka terhadap masukan, melakukan eksperimen baru tanpa takut melakukan kesalahan atau takut menerima kegagalan, mempertajam keterampilan dalam hobi karena dapat meningkatkan kreativitas otak sehingga mampu melahirkan ide-ide segar serta membina hubungan yang luas dengan beragam lingkungan, karakter, dan komunitas berbeda guna memberi kesempatan tumbuhnya kreativitas baru yang mungkin tidak diketahui sebelumnya. Usaha yang dilakukan dapat berupa pembelajaran brainstorming, memberi motivasi, menghadirkan orang-orang kreatif ke sekolah serta tidak membatasi siswa secara berlebihan.

\section{DAFTAR PUSTAKA}

Munandar, Utami. 1992. Mengembangkan Bakat Dan Kreativitas Anak Sekolah (Petunjuk Bagi Guru Dan Orangtua). Jakarta: Gramedia.

Munandar, Utami. 1999. Pengembangan Kreativitas Anak Berbakat. Depdiknas dan Rineka Cipta, Jakarta 
Marmai, Ungsi Antara Oku. (2005). Sistem Penilaian Hasil Belajar Teori dan Praktek Mahasiswa Program Study PKK FT UNP. Makalah disampaikan pada Semlok Peningkatan Kualitas Proses Penilaian Hasil Belajar Teori dan Praktek bagi Dosen Terhadap Mahasiswa PS PKK Jurusan KK FT UNP di Universitas Negeri Padang.

Rahayu, Ani Sri. 2012. Pengembangan Kreativitas Kemandirian. Malang, Yogyakarta. Aditya Media Publishing.

Trianto. (2009). Mendesain Model Pembelajaran Inovatif-Progresif. Jakarta: Prenada Media Group.

Sangari, Ferry Johnny. 2013. Model Pembelajaran Vokasi, Seminar Nasional Pengembangan Pembelajaran Pendidikan Vokasi dalam Perspektif Kurikulum 2013 - Fakultas Teknik, Universitas Negeri Padang 9 November 2013

Samosir, Alfonsus. 1992. Seni Berpikir Kreatif. Jakarta. Erlangga.

Santrock, J.W., 2008, Psikologi Pendidikan, Alih Bahasa Tri Wibowo B.S., Jakarta: Kencana

Supriadi, D. 2001. Kreativitas, Kebudayaan, dan Perkembangan IPTEK. Bandung: ALFABETA.

Ormrod, Jeanne Ellis. 2011. Educational psychology ; Developing Learners (Ed.7). Boston.Pearson. 